\title{
Flere overlever hjertestans
}

\section{Sjansene for å overleve hjertestans utenfor sykehus har økt betydelig de siste årene.}

Tidlig oppstart av hjerte-lunge-redning og defibrillering gir økt sjanse for å overleve hjertestans. Danske helsemyndigheter har de siste ti årene satt i gang flere kampanjer for å få allmennheten til å starte hjerte-lunge-redning og defibrillering ved hjertestans.

En forskergruppe har undersøkt om overlevelsen har økt i perioden (1). Studien om-

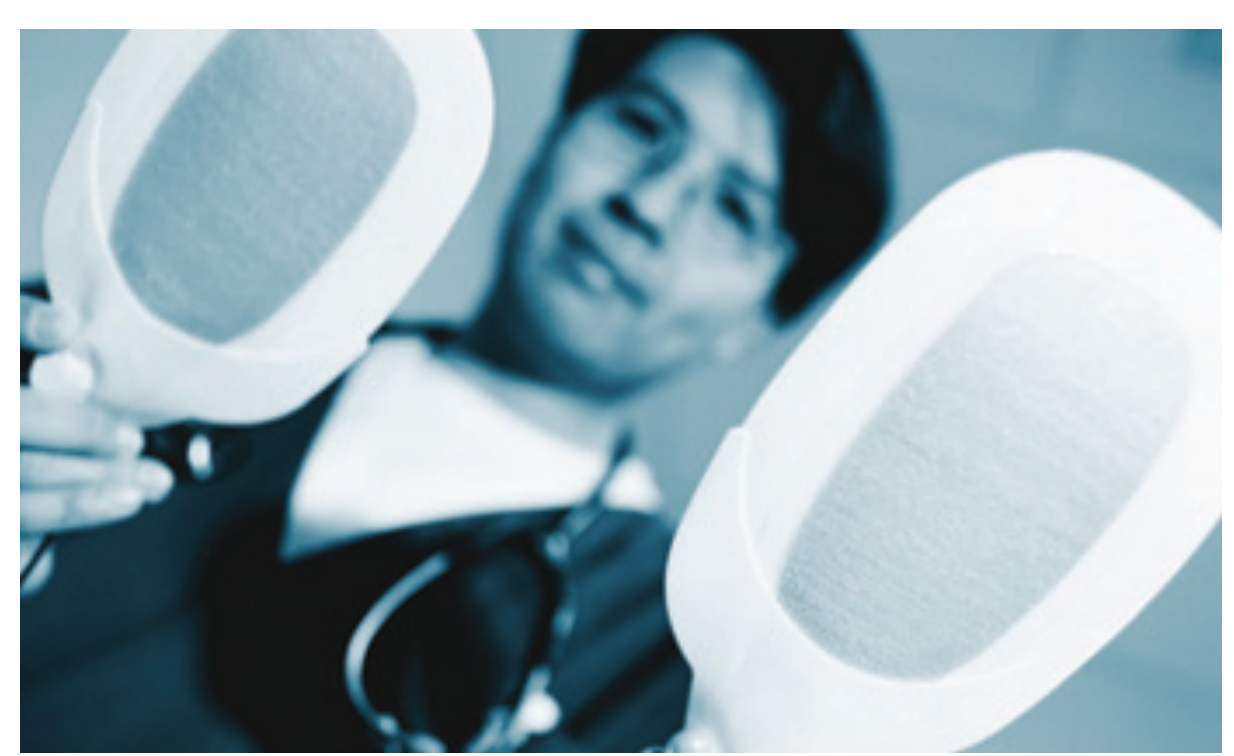

Illustrasjonsfoto: Science Photo Library/NTB scanpix fattet 19468 tilfeller av hjertestans utenfor sykehus. I 2001 ble hjerte-lunge-redning og defibrillator brukt i henholdsvis $21 \%$ og $1,1 \%$ av tilfellene, og 30-dagersoverlevelsen var 3,5\%. I 2010 ble hjerte-lunge-redning startet i $45 \%$ av tilfellene, defibrillator ble brukt i 2,2 \% av tilfellene, og 30-dagersoverlevelsen var $11 \%$. Hjerte-lunge-redning

«kjeden som redder liv» kan øke hjertestanspasienters sjanse til å overleve. Det er forståelig at man ikke kan påvise effekt av en mer omfattende utplassering av hjertestartere, ettersom $60-70 \%$ av alle tilfeller av hjertestans skjer i hjemmet. Vi bør vurdere nye strategier for utplassering av hjertestartere. I tillegg bør vi gjeninnføre obligatorisk opplæring i hjerte-lunge-redning i skolen og i førerkortopplæringen og sikre at livreddende telefoninstruksjon fra AMK-sentralene ikke forsinkes av unødige mellomledd, sier Lexow.

\section{Sigurd Høye}

Tidsskriftet

\section{Litteratur}

1. Wissenberg M, Lippert FK, Folke F et al. Association of national initiatives to improve cardiac arrest management with rates of bystander intervention and patient survival after out-of-hospital cardiac arrest. JAMA 2013; 310: 1377-84.

\section{Trening kan forebygge fallskader hos eldre}

\author{
Et treningsprogram utviklet \\ for å forebygge fall hos eldre \\ gir færre fallskader, også av de \\ mest alvorlige.
}

Tilpassede treningsprogrammer kan forebygge fall hos eldre, men det mangler kunnskap om hvorvidt slik trening også forhindrer alvorlige og moderate skader etter fall. Franske forskere har nå undersøkt dette hos dem over 60 år (1).

Rundt 4300 personer fra 17 randomiserte studier ble valgt ut til en metaanalyse. Fire fallkategorier ble identifisert: de som fører til skader, de som fører til medisinsk behandling, de som fører til alvorlige skader og de som fører til fraktur. Treningen hadde signifikant effekt på alle kategorier, med rateratio på henholdsvis $0,63,0,70,0,57$ og 0,39 . Imidlertid var det signifikant heterogenitet mellom studiene av alle fall som fører til skader $\left(\mathrm{I}^{2}=50 \%, \mathrm{p}=0,04\right)$.

- Denne studien bekrefter hvor viktig trening utviklet av kvalifisert personell har for arbeidet med å forebygge fall og brudd hos eldre, sier fysioterapeut Astrid Bergland, professor ved Fakultet for helsefag, Høgskolen i Oslo og Akershus. - Resultatene tyder på at øvelser som omfatter balanse, styrke, fleksibilitet, utholdenhet og funksjonell trening er mest virkningsfullt. Balansetrening fremheves som en særlig viktig komponent.

- Det ville ha vært av interesse å få klarlagt hvilke typer brudd det refereres til. Den mest alvorlige fallskaden rapportert i litteraturen er hoftebrudd - $90 \%$ av disse skyldes fall. Samtidig er det slik at rundt $5 \%$ av fallene fører til hoftebrudd, sier Bergland, som påpeker at trening er en intervensjon med mange positive virkninger i tillegg til den bruddforebyggende.

Trine B. Haugen

Tidsskriftet

Litteratur

1. El-Khoury F. Cassou B, Charles MA et al. The effect of fall prevention exercise programmes on fall induced injuries in community dwelling older adults: systematic review and meta-analysis of randomised controlled trials. BMJ 2013; 347: f6234. 